\title{
Treatment of cancer with cryochemotherapy
}

\author{
LM Mir*,' and B Rubinsky,3 \\ IFRE 2530 CNRS, Institut Gustave Roussy, PR II, 39, rue Camille Desmoulins, F-94805 Villejuif Cédex, France; ${ }^{2}$ Department of Biomedical Engineering, 6105 \\ Etcheverry Hall, University of California at Berkeley, Berkeley, California, CA 94720, USA; ${ }^{3}$ Department of Mechanical Engineering, 6105 Etcheverry \\ Hall, University of California at Berkeley, Berkeley, California, CA 94720, USA
}

Cryosurgery employs freezing to destroy solid tumours. However, frozen cells can survive and cause cancer recurrence. Bleomycin, an anticancer drug with a huge intrinsic cytotoxicity is normally not very effective because it is nonpermeant. We report that freezing facilitates bleomycin penetration into cells making it toxic to cryosurgery surviving cells at concentrations that are non-toxic systemically. British Journal of Cancer (2002) 86, 1658 - 1660. DOl: 10.1038/sj/bjc/6600306 www.bjcancer.com (c) 2002 Cancer Research UK

Keywords: cryosurgery; frozen tissue; bleomycin

Cryosurgery is a minimally invasive surgical technique that employs freezing to destroy solid tumours. Deep in the body it is performed with needle-like cryogen cooled probes, inserted in the tumour. The extent of freezing is controlled by imaging (Onik et al, 1984, 1991; Rubinsky, 2000). The frozen tissue is left to thaw in situ and is disposed by the body immune system. During cryosurgery, freezing propagates from the cryosurgical probe outward. Cells in the frozen lesion experience a range of temperatures from cryogenic near the probe interface (lower than $-140^{\circ} \mathrm{C}$ ), to phase transformation on the outer edge $\left(-0.56^{\circ} \mathrm{C}\right)$ (Rubinsky, 2000). On the outer rim of the frozen lesion, in the temperature range between $-0.56^{\circ} \mathrm{C}$ and about $-40^{\circ} \mathrm{C}$, cells can survive (Rui et al, 1999; Rubinsky, 2000). Therefore, despite imaging, there is uncertainty in the application of the procedure and at times cryosurgery failure (Revoire et al, 1996).

Bleomycin is an anticancer drug with a huge intrinsic cytotoxicity. It is not very effective because it cannot enter cells freely (Mir et al, 1996; Pron et al, 1999). However, increasing cell membrane permeability with electrical procedures results in a huge increase in bleomycin cytotoxicity, (Belehradek et al, 1993; Mir et al, 1998; Kotnik et al, 2000; Mir, 2001). Our hypothesis was that the change in membrane permeability and increase in extracellular solute concentration during freezing (Mazur, 1970; Rubinsky, 2000) might facilitate penetration of bleomycin in frozen cells which could make it useful in treating cells on the outer rim of the frozen lesion. We tested the hypothesis by freezing cells with thermal parameters typical to the outer rim of the frozen lesion, in which cells survive freezing, in the presence of various doses of bleomycin (Rui et al, 1999; Rubinsky, 2000). This found that freezing facilitates bleomycin penetration into cells, making it toxic to cryosurgery surviving cells at concentrations that are normally non-toxic. Since both cryosurgery and bleomycin are routinely used for clinical treatment of cancer the combination should have immediate clinical utility.

*Correspondence: Dr LM Mir; E-mail: luismir@igr.fr Received 3I October 200I; revised 8 March 2002; accepted I4 March 2002

\section{MATERIALS AND METHODS}

Experiments were performed with B16 F0 melanoma cells (ATCC CRL 6322). First, $100 \mu \mathrm{l}$ of S-MEM (Life Technologies, Rockville, $\mathrm{MD}, \mathrm{USA}$ ) in a $15 \mathrm{ml}$ tube (Falcon, Becton Dickinson, Franklin Lakes, NJ, USA) were frozen in a $-20^{\circ} \mathrm{C}$ freezer, in air, to produce an ice seed. Then $400 \mu \mathrm{l}$ of cells just suspended in ice-cooled SMEM with either $5 \mu \mathrm{M}, 500 \mathrm{~nm}, 100 \mathrm{~nm}$ or $10 \mathrm{~nm}$ of bleomycin or without bleomycin were put in the test tubes with the frozen solution and inserted in the $-20^{\circ} \mathrm{C}$ freezer. A T type thermocouple (Omega, Stamford, CT, USA) which was put in a thermal control sample and used with each experiment has shown that the solutions froze with a cooling rate of $1 \pm 0.2^{\circ} \mathrm{C} / \mathrm{min}$ to a temperature of $-14 \pm 1^{\circ} \mathrm{C}$. The cells were exposed to freezing conditions for $30 \pm 4 \mathrm{~min}$. The frozen samples were thawed by immersion in water at room temperature. They thawed within $10 \mathrm{~min}$. Following thawing the samples were diluted with $2 \mathrm{ml}$ of normal MEM culture medium (Life Technologies) supplemented with $8 \%$ foetal calf serum (Life Technologies) and penicillin and streptomycin (Sarbach/Solvay Pharma, Brussels, Belgium), which resulted in a five times dilution of the bleomycin concentration. Cells were transferred to $35 \mathrm{~mm}$ Petri dishes (TPP, Trasadingen, Switzerland) and incubated at $37^{\circ} \mathrm{C}$ and $5 \% \mathrm{CO}_{2}$ (Universal Water Jacketed Incubator, Forma Scientific, Marietta, OH, USA). Overall viability of the cells was inspected visually immediately after and 3 to $4 \mathrm{~h}$ after the treatment. Six hours after the treatment (i.e. after cell attachment), medium was changed in the experiments in which cells were exposed to $5 \mu \mathrm{M}$ bleomycin in order to reduce the external concentration of the drug to non-cytotoxic levels. In the case of the experiments with $500 \mathrm{nM}, 100 \mathrm{nM}$ or $10 \mathrm{nM}$ bleomycin, the medium was only changed $24 \mathrm{~h}$ after the treatment (it has been shown that for all these concentrations a five times dilution is below the toxic concentration when cell exposure time to bleomycin or bleomycin analogues was $48 \mathrm{~h}$ or longer (Takahashi et al, 1987)). In half of the controls the medium was also changed after $6 \mathrm{~h}$ and in the other half after $24 \mathrm{~h}$, to remove the cells killed by the freezing procedure. No statistical difference in the number of colonies was observed between these two groups of controls. After $137 \mathrm{~h}$ of culture the medium was removed, cells were fixed using $1.5 \mathrm{ml}$ of formol $2 \%$ in $\mathrm{NaCl} 0.9 \%$ for $10 \mathrm{~min}$, and then stained for $15 \mathrm{~min}$ using $2 \mathrm{ml}$ of crystal violet (Labo Moderne, Paris, 
France) diluted to $1: 5$ in water. After extensive rinsing, colonies were manually counted under a binocular microscope Stemi SV6 (Zeiss, Le Pecq, France). Photographs were taken using a Contax 167MT camera (Zeiss) directly installed on an Axiovert 135 (Zeiss) inverted microscope, on $160 \mathrm{~T}$ Ektachrome Kodak films. Slides were scanned using a Mirage S2 scanner (UMAX). Statistical analysis was performed using ANOVA (One Way Analysis of Variance).

\section{RESULTS AND DISCUSSION}

The apparent cell survival immediately after thawing, evaluated from cell membrane integrity and morphology, was low, typical to the tested freezing conditions and relatively similar in all the samples with no discernable trend. This is to be expected as the effect of bleomycin should be long term, to prevent cell division, and not immediately evident. Table 1 compares the long-term survival of B16 F0 melanoma cells, in culture. Six experiments with cells frozen in S-MEM alone show that they produced a mean of $242+153$ colonies. In contrast, bleomycin at concentrations of $5 \mu \mathrm{M}, 500 \mathrm{~nm}$ and $100 \mathrm{~nm}$ caused, in four separate experiments for each concentration, a significant decrease in viability producing a mean of $1 \pm 2,0$, and $0.5 \pm 0.6$ colonies, respectively (statistically different of the controls, $P<0.001$ using ANOVA test). The effect of bleomycin seems to taper off at a concentration of $10 \mathrm{~nm}$, for which four experiments produced a mean of $13 \pm 8.2$ colonies (statistically different of the three other bleomycin groups, $P=0.002$ using ANOVA test).

It is well established in the cryobiology literature that cells can survive freezing. There are various mechanisms of freezing damage and they are complex. On the outer edge of the frozen cryosurgical lesion, where cells survive, the mechanism of damage is due to 'low' cooling rates (Rubinsky and Shitzer, 1976; Rubinsky, 2000). Mazur (1970) explained that at what are considered 'low' cooling rates, ice forms first extracellularly, while the intracellular solution does not freeze and remains supercooled. Ice has a tight crystallo-

Table I Comparison of the survival of B 6 F0 melanoma cells that were frozen in the absence or in the presence of either $5 \mu \mathrm{M}, 500 \mathrm{nM}, 100 \mathrm{nM}$ or I0 nM of bleomycin

\begin{tabular}{lcc}
\hline \multicolumn{2}{c}{ Freezing with bleomycin } & Freezing without bleomycin \\
\cline { 2 - 3 } Dose & Number of clones & Number of clones \\
\hline $5 \mu \mathrm{M}$ & 0 & 507 \\
$5 \mu \mathrm{M}$ & 4 & 232 \\
$5 \mu \mathrm{M}$ & 0 & 59 \\
$5 \mu \mathrm{M}$ & 0 & 304 \\
& & 170 \\
& & 182 \\
$500 \mathrm{nM}$ & Mean: $1 \pm 2$ & \\
$500 \mathrm{nM}$ & 0 & \\
$500 \mathrm{nM}$ & 0 & \\
$500 \mathrm{nM}$ & 0 & \\
& 0 & \\
$100 \mathrm{nM}$ & Mean: 0 & \\
$100 \mathrm{nM}$ & 0 & \\
$100 \mathrm{nM}$ & 1 & \\
$100 \mathrm{nM}$ & 0 & \\
& 1 & \\
$10 \mathrm{nM}$ & Mean: $0.5 \pm 0.6$ & \\
$10 \mathrm{nM}$ & 11 & \\
$10 \mathrm{nM}$ & 25 & \\
$10 \mathrm{nM}$ & 7 & \\
& 9 & \\
& Mean: $13 \pm 8.2$ &
\end{tabular}

Viability was determined by the measurement of the cloning efficiency of the cells surviving to the freezing. graphic structure and rejects the solutes in the unfrozen region, usually around the unfrozen cells. To equilibrate the difference in chemical potential across the cell membrane water leaves the cell to freeze in the extracellular space. The consequent cell dehydration causes an increase in intracellular cell osmolality. Cell dehydration together with cell membrane lipid phase transition and transmembrane ionic leakage combine to produce chemical damage to intracellular components. The range of temperatures in which the chemical damage takes place is between the phase transition temperature, $-0.56^{\circ} \mathrm{C}$, and the saline eutectic, about $-32^{\circ} \mathrm{C}$. While the mechanism of damage is the same in the entire temperature range, the extent of the damage increases with lower temperatures and with time of exposure. The thermal parameters employed in this study were chosen because they are typical of non-lethal freezing thermal parameters most relevant to the problems of cryosurgery. The cooling rate of $1^{\circ} \mathrm{C} / \mathrm{min}$ is typical to 'low' cooling rates (Rubinsky and Shitzer, 1976, 2000), the temperature of $-14^{\circ} \mathrm{C}$ is a typical temperature in which cell survival was observed and in which the mechanism of damage is chemical (Revoire et al, 1996; Rui et al, 1999; Rubinsky, 2000) and the time of exposure of $30 \mathrm{~min}$ is typical to how long a cryosurgical procedure takes (Onik et al, 1984, 1991).

Table 1 demonstrates that bleomycin has the ability to significantly increase cell damage at thermal conditions typical to those on the outer rim of a cryosurgical lesion. Bleomycin molecules form complexes with $\mathrm{Fe}^{2+}$ and $\mathrm{O}_{2}$ that directly generate breaks on DNA through the nucleophilic attack of the $\mathrm{C}_{4}^{\prime}$ of the desoxyribose, particularly at the GC sequences (Povirk et al, 1989; Mir et al, 1996). Since bleomycin must penetrate the cell to affect cell survival, the data presented in Table 1 suggests that the bleomycin has entered the cells during freezing and that it is affecting cells which otherwise would have survived the freezing protocol. Figure 1 confirms this. It shows the appearance of cells grown after freezing with and without bleomycin, after $137 \mathrm{~h}$ of culture. The cells that survived the freezing procedure and were not exposed to bleomycin attached to the substrate and kept normal morphology as well as growth features (Figure 1A). On the contrary, in the presence of bleomycin at the time of cell freezing, the attached cells did not show mitoses and their morphology was very altered (Figure 1B). Moreover, these figures show 'mitotic cell death' typical of bleomycin internalisation (Tounekti et al, 1993, 2001).

While an anticancer drug with a huge intrinsic cytotoxicity (several hundred molecules of bleomycin inside the cell are sufficient to kill (Poddevin et al, 1991), mediated by the generation of DNA double-strand breaks), bleomycin is normally not very effective for treatment of cancer because it is nonpermeant (it enters cells not by diffusion through the plasma membrane (Poddevin et al, 1991) but rather by a mechanism of receptormediated endocytosis) (Mir et al, 1996; Pron et al, 1999). There is abundant evidence to show that concentrations of $500 \mathrm{~nm}$ and $100 \mathrm{~nm}$ bleomycin have no effect on cells (Barranco and Humphrey, 1971; Takahashi et al, 1987; Mir et al, 1996). This study demonstrates that bleomycin at doses as low as $100 \mathrm{~nm}$, and even $10 \mathrm{~nm}$, has the ability to significantly reduce the survival of cells frozen with thermal conditions typical of the outer rim of the cryosurgical frozen lesion. For the bleomycin to function at these low concentrations there must be a mechanism by which it can enter the cells during freezing. It is established that the cell membrane is permeabilised during cooling and freezing due to such mechanisms as lipid phase transition, dehydration induced membrane deformation and ice crystal induced membrane deformation (Mazur, 1970; Quinn, 1985). In addition, as discussed earlier, because ice cannot contain solutes, the effect of freezing is to reject all the solutes in the unfrozen region, around the cells. This usually increases the ionic concentration around the cell; however, when bleomycin is present in the solution the concentration of bleomycin near the cell will also 
A

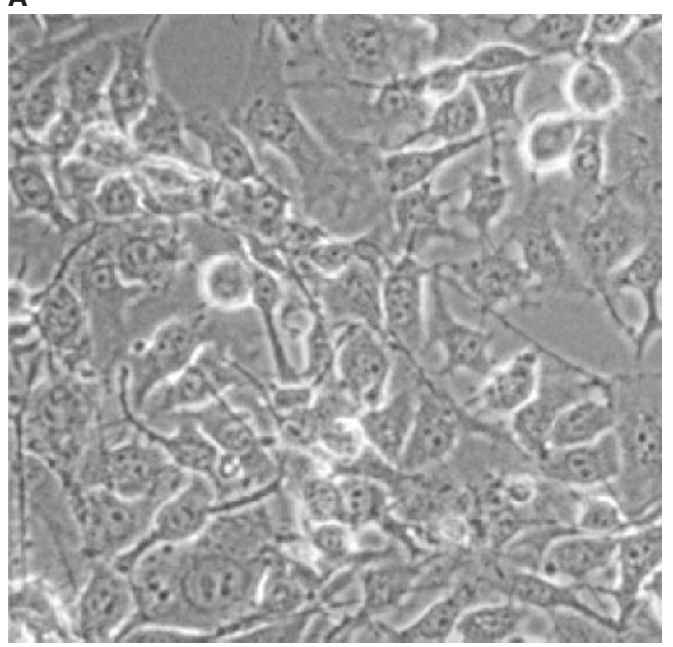

B

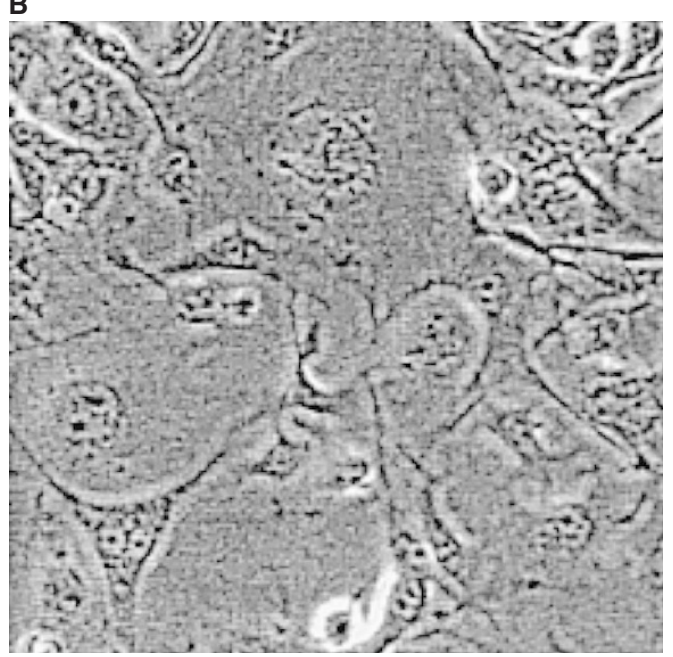

Figure I Typical morphological differences between BI6 F0 melanoma cells that were frozen in the absence $(\mathbf{A})$ or in the presence of $100 \mathrm{~nm}$ of bleomycin (B), after $137 \mathrm{~h}$ of incubation. (Magnification II00 ×). In the absence of bleomycin, the surviving cells display a normal morphology, regular cell size, and the usual nucleus aspect. Normal mitosis can be observed in the two rounded cells on the right upper part of panel A. In contrast, in panel B cells show abnormal morphology. The size of the nuclei and cytoplasm has increased. The limits of the nucleus are not always demarcated while the cytoplasm itself is clear. Among cells there are large differences in nuclei and cell size.

increase. Therefore we propose that the temporary increase in membrane permeability during cooling and freezing, as well as the freezing-induced increase in bleomycin concentration around cells will cause the bleomycin to enter cells during cryosurgery, when used at doses that otherwise would have no effect on the cells.

\section{REFERENCES}

Barranco SC, Humphrey RM (1971) The effects of bleomycin on survival and cell progression in Chinese hamster cells in vitro. Cancer Res 31: $1218-$ 1223

Belehradek M, Domenge C, Luboinski B, Orlowski S, Belehradek Jr J, Mir LM (1993) Electrochemotherapy, a new antitumor treatment: first clinical phase I-II trial report. Cancer 72: 3694-3700

Kotnik T, Macek-Lebar A, Miklavčič D, Mir LM (2000) Evaluation of cell membrane electropermeabilization by means of a nonpermeant cytotoxic agent. BioTechniques 28: $921-926$

Mazur P (1970) Cryobiology: the freezing of biological systems. Science 68 : 939-949

Mir LM, Tounekti O, Orlowski S (1996) Bleomycin: revival of an old drug. Gen Pharmacol 27: $745-748$

Mir LM, Glass FL, Serša G, Teissié J, Domenge C, Miklavčič D, Jaroszeski MJ, Orlowski S, Reintgen DS, Rudolf Z, Belehradek M, Gilbert R, Rols MP, Belehradek Jr J, Bachaud JM, DeConti R, Štabuc B, Coninx P, Čemažar M, Heller R (1998) Effective treatment of cutaneous and subcutaneous malignant tumors by electrochemotherapy. $\mathrm{Br}$ J Cancer 77: 2336-2342

Mir LM (2001) Therapeutic perspectives of in vivo cell electropermeabilization. Bioelectrochem 53: $1-10$

Onik G, Gilbert J, Haddick WK, Filly RA, Collen PW, Rubinsky B, Christianson M (1984) Ultrasonic characteristics of frozen liver. Cryobiology 21: $321-328$

Onik G, Rubinsky B, Zemel R, Weaver L, Kane R (1991) Ultrasound-guided hepatic cryosurgery in the treatment of metastatic colon carcinoma. Preliminary results. Cancer 67: $901-907$

Poddevin B, Orlowski S, Belehradek Jr J, Mir LM (1991) Very high cytotoxicity of bleomycin introduced into the cytosol of cells in culture. Biochem Pharmacol 42(S): $67-75$

\section{ACKNOWLEDGEMENTS}

This work was supported by grants from the Centre National de la Recherche Scientifique the Institut Gustave-Roussy and the 'Prostate Cancer Research and Education Foundation, San Diego, CA, USA'.

Povirk LF, Han YH, Steighner RJ (1989) Structure of bleomycin-induced DNA double-strand breaks: predominance of blunt ends and single-base $5^{\prime}$ extensions. Biochemistry 28: $5808-5814$

Pron G, Mahrour N, Orlowski S, Tounekti O, Poddevin B, Belehradek Jr J, Mir LM (1999) Internalisation of the bleomycin molecules responsible for bleomycin toxicity: a receptor-mediated endocytosis mechanism. Biochem Pharmacol 57: 45-56

Quinn PJ (1985) A lipid phase separation model of low temperature damage to biological membranes. Cryobiology 22: 128-147

Revoire ML, Voiglio EJ, Kaemmerlan P (1996) Hepatic cryosurgery precision: evaluation of ultrasonography, thermometry and impedancemetry in a pig model. J Surg Oncol 61: 242-248

Rubinsky B, Shitzer A (1976) Analysis of a Stefan-Like problem in a biological tissue around a cryosurgical probe. J of Heat Transfer, ASME Transactions 98: $514-519$

Rubinsky B (2000) Cryosurgery. In Ann Rev Biomed Eng Vol 2, Yarmusch ML, Diller KR, and Toner M (eds) pp 157-187. California: Palo Alto

Rui J, Tatsutani KN, Dahiya R, Rubinsky B (1999) Effect of thermal variables on human breast cancer in cryosurgery. Breast Cancer Res Treat 53: $182-$ 192

Takahashi K, Ekimoto H, Minamide S, Nishikawa K, Kuramochi H, Motegi A, Nakatani T, Takita T, Takeuchi T, Umezawa H (1987) Liblomycin, a new analogue of bleomycin. Cancer Treat Rev 14: 169-177

Tounekti O, Pron G, Belehradek Jr J, Mir LM (1993) Bleomycin, an apoptosis-mimetic drug that induces two types of cell death depending on the number of molecules internalized. Cancer Res 53: 5462-5469

Tounekti O, Kenani A, Foray N, Orlowski S, Mir LM (2001) The ratio of single- to double-strand DNA breaks and their absolute values determine cell death pathway. Br J Cancer 84: 1272-1279 